\author{
Roman Krzywy \\ https://orcid.org/oooo-oooI-9964-7362 \\ Instytut Literatury Polskiej \\ Uniwersytet Warszawski
}

\title{
Sielskie bytowanie szlachty a stanowe powinności rycerskie w świetle staropolskiej poezji ziemiańskiej
}

Artykuł omawia stanowiska twórców poezji ziemiańskiej, rzadko ostatnio badanej, wobec militarnych zobowiązań stanu szlacheckiego. Narodziny nurtu w drugiej połowie XVI w. oznaczały zarówno aprobatę dla rolniczego trybu życia, jak i pojawienie się w literaturze staropolskiej konkurencyjnego modelu wobec wzorca rycerskiego. Autor studium, śledząc w porządku chronologicznym wypowiedzi najważniejszych pisarzy ziemiańskich z XVI i XVII w. (Jana Kochanowskiego, Andrzeja Zbylitowskiego, Józefa Domaniewskiego, Stanisława Słupskiego, Władysława Stanisława Jeżowskiego, Zbigniewa Morsztyna, Marcina Borzymowskiego, Wacława Potockiego, Wespazjana Kochowskiego), zamierza ukazać, w jaki sposób piewcy wiejskiej arkadii szlacheckiej odnosili się do etosu militarnego. Zagadnienie to traktowane było dotąd w literaturze przedmiotu jedynie zdawkowo.

The article discusses the attitudes of the authors of the so-called landowning poetry towards the military obligations of the noble estate, which have rarely been studied recently. The birth of this trend in the second half of the sixteenth century meant both an approval for the agricultural lifestyle and the appearance in Old Polish literature of a model competing with the knightly one. The author of the study, following in chronological order the statements of the most important sixteenth- and seventeenth-century writers of this genre (Jan Kochanowski, Andrzej Zbylitowski, Józef Domaniewski, Stanisław Słupski, Władysław Stanisław Jeżowski, Zbigniew Morsztyn, Marcin Borzymowski, Wacław Potocki, Wespazjan Kochowski), intends to indicate how 
the eulogists of the rural noble arcadia referred to the military ethos. Until now, this issue has been treated in the literature only perfunctory.

Słow a kl u c zow e: literatura staropolska, poezja ziemiańska, etos rycerski, szlachta polska

Ke y w o r d s: old Polish literature, landowning poetry, knightly ethos, Polish nobility

Można dość precyzyjnie określić, kiedy etos ziemiański został proklamowany przez polskich literatów, a tym samym wskazać moment, w którym szlachta zaczęła się utożsamiać z ideałem osobowym homo rusticus, jej przedstawiciele zaś propagować ów wzorzec jako z różnych względów najwłaściwszy. Nastąpiło to mianowicie w pierwszych dekadach drugiej połowy XVI stulecia, gdy kilku autorów postanowiło wierszem i prozą wyrazić przekonanie, że ziemiański model egzystencji jest odpowiedni dla stanu szlacheckiego jako zapewniający wszystko, co niezbędne do życia, gwarantując spokój, bezpieczeństwo, niezależność, względny dostatek, szczęście rodzinne, a także wiele przyjemności wynikających choćby z obcowania z naturą czy kontaktów sąsiedzkich. Podjęcie tej tematyki przez ludzi pióra nie było wybiegającą w przyszłość projekcją, lecz stanowiło konsekwencję trudnienia się przez szlachtę zajęciami gospodarskimi, co stawało się normą, począwszy od wieku $\mathrm{XV}^{1}$.

Za najstarszy znany dziś utwór afirmujący idee ziemiańskie uchodzi anonimowa pieśń o incipicie „Spokojny kąt komu Bóg dał i myśl spokojną...”, przechowana w nieistniejącym już manuskrypcie zawierającym miscellanea spisane w latach $1550-1560^{2}$. Jest to zarazem pierwsza polska parafraza Horacjuszowej epody drugiej, która poprzedza wypowiedzianą ustami Panny XII pochwałę życia wiejskiego

1 Zob. A. Wyczański, Polska - rzecza pospolita szlachecka 1454-1764, Warszawa 1965, s. 58-59; J. Maciszewski, Szlachta polska i jej państwo, Warszawa 1969, s. 73-74. Ostatnio wysunięto hipotezę, że szlachta zajmowała się rolnictwem z dawien dawna, o czym świadczyć mogą występujące już w najstarszych herbach (XIII w.) narzędzia gospodarskie, przekonanie zaś o pochodzeniu od wojowników stanowi rodzaj tradycji wynalezionej; zob. M. Cetwiński, Narzędzia gospodarcze $w$ heraldyce jako świadectwo przemian szlacheckiego etosu, „Rocznik Polskiego Towarzystwa Heraldycznego" n.s., 18, 2019, s. 5-11.

2 Zob. A. Brückner, Wiersze zbieranej drużyny, „Biblioteka Warszawska”, 1891, 3, s. 414. W rękopisie pomieszczono materiały dotyczące wydarzeń z 1547 r. i następnych. 
w ogłoszonym po raz pierwszy drukiem w roku 1586 cyklu sobótkowym Jana Kochanowskiego. Pieśń świętojańska znana jest również z redakcji rękopiśmiennej zachowanej w sylwie zbierającej materiały z lat sześćdziesiątych i siedemdziesiątych XVI w., co pozwala sądzić, że pierwodruk poprzedził kolportaż w formie odpisów. Powstanie cyklu łączy się z porzuceniem służb dworskich i zamieszkaniem poety w Czarnolesie. Biorąc to pod uwagę, a także inne przesłanki, określa się datę powstania zbioru na pierwszą połowę lat siedemdziesiątych $^{3}$. Decyzja o powrocie na ojcowiznę znalazła też odzwierciedlenie w dwóch innych wypowiedziach poetyckich, które również afirmują wartości ziemiańskie: kilku łacińskich elegiach z księgi trzeciej $(2,13,14,15)$ zbioru opublikowanego w 1584 (Elegiarum libri quattuor) oraz polskojęzycznym Marszatku wydanym w roku 1585. Te autobiograficzne utwory zalecają wiejski żywot jako taki, który pozwala hołdować zasadzie złotej mierności, zapewnia spokój i niezależność ${ }^{4}$.

Tekstom wierszowanym wtórowały prozaiczne. Najobszerniejsze dzieło, w którym dobitnie wyraża się aprobata dla kondycji ziemiańskiej, to oczywiście Żywot cztowieka poczciwego, wchodzący w skład ogłoszonego po raz pierwszy w 1568 i wznowionego w roku 1606 opasłego tomu Mikołaja Reja, zatytułowanego Źwierciadto albo Kstatt, w którym każdy stan snadnie sie może swym sprawam, jako we źwierciadle, przypatrzyć. Tytuł kompendium jednoznacznie zapowiada intencje parenetyczne. Część wizerunkowa przedstawia - jak dobrze wiadomo - wzorcową egzystencję szlachcica od narodzin do śmierci, nadając wiejskiemu bytowaniu pozytywny wymiar etyczny (tytułowa „poczciwość" to tyle co uczciwość, przyzwoitość, ale też obyczajność, cnotliwośćs ${ }^{5}$, religijny (życie pobożne), ekonomiczny (dostatek własny, ale i dobrobyt państwa), społeczny (z kultem rodziny na czele), ale też przyjemnościowy. Podobne aspekty wziął pod uwagę Jakub Ponętowski w napisanym przed rokiem 1586 liście do kasztelana podlaskiego Marcina Leśniowolskiego, wyznaczając granice aspiracji szlacheckiego gospodarza do jednej, ale zasobnej w kmieci i dobrze urządzonej wsi. List krążył w obiegu rękopiśmiennym (do

3 Zob. J. Pelc, Rękopiśmienna wersja „Sobótki” Jana Kochanowskiego, w: Miscellanea staropolskie. 3, [red. R. Pollak], Wrocław 1969 (Archiwum Literackie, t. 14), s. $20-21$.

4 Zob. A. Karpiński, Staropolska poezja ideatów ziemiańskich. Próba przekroju, Wroclaw 1983, s. 182-185.

5 Zob. Stownik polszczyzny XVI wieku, t. 25, Warszawa 1997, s. 262-263. Autorzy hasła uznają wyrażenie 'człowiek poczciwy' za odpowiednik łac. vir honestus. 
czasów współczesnych zachowały się trzy kopie), lecz ukazał się także drukiem. W okrojonej redakcji został opublikowany pod nagłówkiem Ziemianin w Gospodarstwie Anzelma Gostomskiego z 1588, przedrukowanym bez większych zmian w roku 1606. Do poradnika tekst włączył najprawdopodobniej wydawca bez wiedzy autora ${ }^{6}$. W wieku XVII przewierszował epistołę arianin Mikołaj Lubieniecki, nadając swej parafrazie tytuł Kondycyja szlachecka ${ }^{7}$.

Przywołane utwory inicjują bogatą odmianę piśmiennictwa obejmującą teksty prozą i zwłaszcza wierszem, które zalecały żywot wiejski jako najlepszy z możliwych i godny kondycji reprezentantów stanu szlacheckiego. Zjawisko to uznaje się czasem za cechę swoiście polską. Jak przekonywał z pewną przesadą Claude Backvis, chociaż w całej siedemnastowiecznej Europie rolnictwo było głównym źródłem dochodów warstw panujących, to w Rzeczypospolitej jego epifenomenem była również obfita twórczość poetycka stanowiąca wyrazisty nurt pisarski ${ }^{8}$.

Wymienione wyżej utwory Kochanowskiego, który wytyczył drogę dalszego rozwoju poezji polskiej (wzorzec Rejowy szybko stracił na znaczeniu), uzmysławiają kilka istotnych dla odbioru twórczości ziemiańskiej problemów. Pieśń Panny XII z Pieśni świętojańskiej o sobótce, a także jej bezimienna poprzedniczka to parafrazy utworu Horacego, którego topikę przejęły, odrzucając wymowne zakończenie sugerujące iluzoryczność mrzonek lichwiarza Alfiusza. To rozwiązanie zaakceptowali następcy. Odwołując się zwykle w mniej lub bardziej

${ }^{6}$ Gostomski zmarł w roku publikacji. Wydawca Gospodarstwa przypuszczał, że list Ponętowskiego znajdował się w papierach autora dostarczonych typografowi; zob. S. Inglot, Wstęp, w: A. Gostomski, Gospodarstwo, Wrocław 1951, s. XXII-XXIII.

Utwór znany z kopii z 1660 r. zachowanej w odpisie Andrzeja Lubienieckiego; zob. S. Kot, Urok wsi i życia ziemiańskiego w poezji staropolskiej, Warszawa 1937, s. 76. Za pochodną listu Ponętowskiego uważa się też czasem chętnie kopiowaną w XVII w. Szlachecka kondycyję Hieronima Morsztyna; zob. A. Krzewińska, Pieśń ziemiańska, antyturecka i refleksyjna. Studia nad wybranymi gatunkami staropolskiej liryki XVI i XVII wieku, Toruń 1968, s. 74; A. Karpiński, op. cit., s. 162, 167.

8 Zob. C. Backvis, Panorama poezji polskiej okresu baroku, t. 1, tł. W. Błońska-Wolfratch, A. i K. Choińscy, G. Majcher, red. nauk. A. Nowicka-Jeżowa, R. Krzywy, Warszawa 2003, s. 380-381. Nurt był żywotny w literaturze polskiej jeszcze w XIX w., kiedy to podjęto, nieudane zresztą, próby identyfikacji ideałów ziemiańskich z polskością; zob. na ten temat A. Witkowska, Stawianie, my lubim sielanki..., Warszawa 1972. Pamiętać oczywiście należy, że utwory przeciwstawiające żywot wiejski innym nie były nieznane literaturom europejskich; zob. A. Karpiński, op. cit., s. 11-12. 
widoczny sposób przede wszystkim do modelu czarnoleskiego, poeci sięgali również często do źródeł antycznych, głównie obszernej dygresji z księgi drugiej Georgik Wergiliusza, zawierającej pochwałę życia rolnika9 ${ }^{9}$ a także niektórych pieśni Horacego, elegii Tibullusa czy twórczości bukolicznej ${ }^{10}$. Oznacza to, że treści wyrażone we wzorcowych utworach starożytnych traktowano jako uniwersalne, ale i do pewnego stopnia umowne, służące prezentacji konkretnego ideału, który nie korespondował całkowicie z rzeczywistością, lecz ją zgodnie z obowiązującą tendencją estetyczną idealizował, by nadać przedstawianej wizji przekonujący kształt. Najjaskrawiej uwidacznia się ta tendencja we wprowadzeniu do opisów ziemiańskiej wsi komponentów bukolicznych, służących przede wszystkim idealizacji przestrzeni i życia wiejskiego ${ }^{11}$. Do tego rodzaju zabiegów należy również nierzadko stylizowanie podmiotu na oracza czy pasterza (lub podobną umowną figurę), samodzielnie wykonującego prace polowe i doglądającego trzody. Kreując się na kogoś takiego w Marszatku i zarazem parafrazując Tibullusa, Kochanowski - poeta doctus - nie bez kozery nadmienił:

Tak poeta mój śpiewa, a znam i po rymie,

Że sam roli nie orał ani siadał w dymie,

Ale żywot spokojny i miarę miłował,

$\mathrm{W}$ czym bym go rad jako $\mathrm{i} w$ rymie naszladowat ${ }^{12}$.

(w. 53-56)

9 Cały zbiór stanowił dla pisarzy staropolskich ważny przekaz nie tylko jako źródło topiki, lecz również jako koncepcja antropologiczna, Wergiliusz bowiem uznał żywot rolnika za pozwalający osiągnąć wolność osobistą, spokój wewnętrzny i szczęście, zachować umiar w zakresie potrzeb materialnych, a także czystość obyczajów oraz kultywować pobożność. W koncepcji tej nietrudno dostrzec inspiracje zarówno filozofią epikurejską, którą rzymski poeta studiował w młodości, jak i stoicyzmem zespolonym z programem sanacyjnym Oktawiana Augusta. Co równie istotne, w odróżnieniu od wizji szczęścia zarysowanej w Bukolikach, georgiczna arkadia nie jest łączona z jakąś odległą krainą, lecz ze wsią italską.

10 Zob. A. Karpiński, op. cit., s. 14-21, 169-180, 183-184; J. S. Gruchała, S. Grzeszczuk, Staropolska poezja ziemiańska, w: Staropolska poezja ziemiańska. Antologia, oprac. J. S. Gruchała, S. Grzeszczuk, Warszawa 1988, s. 28-41, 65-76.

11 Zob. A. Karpiński, op. cit., s. 176.

12 J. Kochanowski, Marszatek, w: idem, Dzieta polskie, oprac. J. Krzyżanowski, Warszawa 1982, s. 116; zob. też A. Karpiński, op. cit., s. 33-35, 79, 183. Nawiązanie do Tibullusa wpisuje się w szerszy program imitacyjny Kochanowskiego, widoczny zwłaszcza w jego elegiach; zob. J. Glomski, The Role of „imitatio” in Jan Kochanowski's „Elegiae”, „Lyricorum libellus”, and „Pieśni”, „Oxford Slavonic Papers", 20, 1987, s. 40-48. 
Wielu twórców przyjęło tę fikcję podmiotową, choć nie ma wątpliwości, że służyła ona wyrażeniu autentycznych treści światopoglądowych, a nawet dawała sposobność utrwalenia - jak w przypadku Jana z Czarnolasu - sytuacji z własnej biografii.

Wspomniane zabiegi pozwalają, jak sądzę, traktować poezję ziemiańską jako rodzimą inkarnację tematu bukoliczno-arkadyjskiego ${ }^{13}$. Był to jeden $\mathrm{z}$ trzech - obok kultu bohaterów wojennych oraz pragnienia mądrości polegającej na wyrzeczeniu się świata doczesnego wielkich mitów społecznych czy też tematów dawnej sztuki i literatury, które formowały wyobrażenia o życiu zacnym i szczęśliwym. Jak zwięźle a trafnie rzecz ujął Johan Huizinga:

$\mathrm{Na}$ tych kilku tematach: bohaterstwie, mądrości i motywie bukolicznym opierała się od czasów starożytnych cała kultura literacka. Średniowiecze, odrodzenie, wiek XVIII i XIX nie wymyśliły tu prawie nic więcej poza nowymi wariacjami tej samej melodii ${ }^{14}$.

Piśmiennictwo Rzeczypospolitej nie było w tym względzie żadnym wyjątkiem, aczkolwiek interesować winny oczywiście rodzime wariacje owych melodii. Z pewnością należy do nich nadanie szlacheckiej arkadii cech georgicznych, którą motywy bukoliczne jedynie urozmaicały. Obwieszczony przez literaturę renesansową etos ziemiański nie mógł też zupełnie zlekceważyć ideałów militarnych, zarówno z uwagi na ich tradycyjność, jak i atrakcyjność. Wartości rycerskie należały bowiem do najtrwalszych składników szlacheckiej ideologii stanowej ${ }^{15}$.

${ }^{13}$ Jak zauważył R. Karpiński w recenzji z opracowanej przez J. S. Gruchałę i S. Grzeszczuka antologii Staropolska poezja ziemiańska („Przegląd Historyczny”, 81, 1990, 3/4, s. 710): „Wszak średniozamożny szlachcic tego okresu to człowiek zupełnie inny [niż bohater literatury ziemiańskiej - R.K.]. Posiadający stały kontakt z rynkiem, ruchliwy, organizujący spław, a w najgorszym razie transport do portu, nie stroniący od kupowania nadwyżek zbożowych z chłopskich gospodarstw, aktywny w życiu politycznym. Literatura ziemiańska kreowała mit, a więc ukazywać może tęsknoty za niezrealizowanym sielankowym życiem, podobnie jak operowała frazesami jakże rozmijającymi się z rzeczywistością". Zob. też A Krzewińska, op. cit., s. 61; U. Świderska-Włodarczyk, Homo nobilis. Wzorzec szlachcica w Rzeczypospolitej XVI i XVII wieku, Warszawa 2017, s. $115-122$.

${ }_{14}$ J. Huizinga, Jesień średniowiecza, tł. T. Brzostowski, wstęp H. Barycz, posł. S. Herbst, Warszawa 1992, s. 61; por. S. Graciotti, Podwójne oblicze baroku, tt. W. Jekiel, „Barok”, 2, 1995, 2, s. 12-15.

15 Przekonuje o tym dobitnie lektura książki S. Baczewskiego Szlachectwo. Studium z dziejów idei w piśmiennictwie polskim (druga potowa XVI wieku - XVII wiek), Lublin 2009; zob. też M. Kuran, Obraz rycerstwa-szlachty w literaturze 
O ich aktualności przypominano nieprzerwanie, począwszy od kronik średniowiecznych poprzez niezliczone panegiryki, pobudki wojenne, kazania pogrzebowe aż po epikę bohaterską z początków XIX w. i późniejszą twórczość patriotyczną, łącząc je w kulturze szlacheckiej z dziedzictwem przodków (schedą po walecznych Sarmatach, zwykle wyolbrzymianymi albo zgoła wymyślonymi przewagami wojennymi pradziadów czy też z oboma tymi mityzowanymi tradycjami jednocześnie). Podtrzymywaniem pamięci o walecznych antenatach zainteresowani byli zresztą sami herbowni, dbając o tworzenie sięgających $\mathrm{w}$ przeszłość legend rodowych, a jednocześnie utrwalając przekonanie, że szlachetni wywodzą się jedynie ze szlachetnych. Zapewniło to ideałom rycerskim dużą siłę oddziaływania oraz bardzo długą żywotność, przejawiającą się w kolejnych adaptacjach archaicznego etosu ${ }^{16}$. Są to zagadnienia stosunkowo dobrze rozpoznane.

Pojawienie się konkurencyjnego modelu egzystencjalnego musiało doprowadzić do swoistej dialektyki w zakresie uznawanych przez szlachtę wartości. By ją naświetlić, warto przyjrzeć się należącym do nurtu ziemiańskiego utworom wierszowanym, gdyż to one stanowiły podstawowe medium w propagowaniu georgicznych ideałów, zwracając baczniejszą uwagę na to, w jaki sposób jej autorzy radzą sobie z rycerską etyką ojców. W moim przekonaniu problematyka ta nie została dotąd wystarczająco przebadana. W literaturze przedmiotu znaleźć można jedynie wzmianki na ten temat, które nie do końca oddają faktyczny stan rzeczy.

Odwoływać się będę do tekstów reprezentujących rozmaite formy: łacińskiej elegii, epiki historycznej, pieśni czy rymowanej publicystyki, zatem do twórczości zróżnicowanej gatunkowo i mającej nierzadko rozmaite przeznaczenie, co wymagać będzie respektowania swoistości omawianych utworów. W przeglądzie skupię się na wierszowanych wypowiedziach programowych i parenetycznych, pominę wiersze $\mathrm{w}$ nikłym stopniu nacechowane ideologicznie (jak np. opisy sąsiedzkich biesiad). Uwzględnione zostaną głosy przedstawicieli stanu ziemiańskiego, na boku pozostawię zaś wypowiedzi mieszczan (Jana Rybińskiego, Macieja Wirzbięty, Sebastiana Fabiana Klonowica,

okolicznościowej i parenetycznej początku XVII w., „Rocznik Polskiego Towarzystwa Heraldycznego" n.s., 18, 2019, s. 91-122.

$16 \mathrm{O}$ trwałości polskiego kultu męstwa wojennego od XVI po XX stulecie zob.

T. Tomasik, Wojna - meskość - literatura, Słupsk 2013, s. 73-166; A. Stroynowski, „Śmierć chwalebna” w propagandzie patriotycznej epoki stanistawowskiej, „Kwartalnik Historii Kultury Materialnej”, 64, 2016, 2, s. 239-248. 
Sebastiana Petrycego, Kaspra Twardowskiego) bądź magnatów (Stanisław Miński, Łukasz Opaliński, Jan Andrzej Morsztyn) czy magnackich dworzan (Daniel Naborowski).

Wskazany cel wymaga sięgnięcia do wydań zawierających kompletne utwory wraz z ramą wydawniczą, gdyż wyimki publikowane $\mathrm{w}$ antologiach skupiają się zwykle na obrazie ziemiańskiej arkadii, a pomijają to, co z nią sprzeczne, nie pozwalając wydobyć interesującego mnie napięcia. Wbrew dominującej i ze wszech miar uzasadnionej praktyce typologicznego omawiania tej twórczości, w niniejszym przeglądzie przyjęto ujęcie diachroniczne, które pozwoli lepiej zaprezentować badane zagadnienie w powiązaniu z kontekstem biograficznym i historycznym. Wybór takiej perspektywy uzasadnia również pojawianie się głosów polemicznych w obrębie nurtu.

Abstrahować przy tym będę od realnego znaczenia szlachty dla obronności państwa i motywów wstępowania jej przedstawicieli do armii ${ }^{17}$. Zadeklarować też wypada na wstępie świadomość fragmentaryczności proponowanego ujęcia, które nie roszcząc sobie prawa do pełnej panoramy, znajduje wszak solidne oparcie w literaturze przedmiotu, pozwalającej na formułowanie sądów ogólniejszej natury ${ }^{18}$.

Wkraczający do literatury polskiej mit arkadii ziemiańskiej od samego początku sytuowano bądź w opozycji wobec rycerskiego etosu ojców, bądź oba porządki wartości starano się na różne sposoby uzgadniać. Przykładowo w publikowanym kilkakrotnie w latach 1563-1564 Satyrze albo Dzikim mężu Kochanowskiego tytułowy bohater bez ogródek zarzuca szlachcie chciwość, która jego zdaniem doprowadziła do poniechania chlubnych tradycji i oddania się zajęciom gospodarskim oraz handlowi. Krytykowanej zmianie bożek przeciwstawił wychowanie żołnierskie ujęte w formę zwierciadła adresowanego do młodego władcy. Bohater nie jest, nadmienić należy, rezonerem autora, przekazuje treści aktualnej publicystyki. Dość wspomnieć, że w elegii III 15 poeta jak najbardziej

17 Zob. syntetyczne ujęcia: R. Gałaj, Życie codzienne szlachty polskiej w okresie sarmatyzmu, Szczecin 1998, s. 102-117; T. Srogosz, Życie codzienne żotnierzy armii koronnej i litewskiej w XVII wieku, Oświęcim 2018, s. 25-38.

18 Najlepszą monografią zjawiska pozostaje przywoływana wyżej książka A. Karpińskiego; zob. też obszerny wstęp J. S. Gruchały i S. Grzeszczuka w antologii Staropolska poezja ziemiańska. 
opowiadał się za krytykowanym w poemacie sposobem zarobkowania, „irato Satyrus frendeat ore licet” („choć zgrzytając zębami Satyr się pogniewa”, w. 42) ${ }^{19}$. Z kolei Rej w biografii modelowego szlachcica-ziemianina przewidywał miejsce na przygotowanie militarne, doceniając sprawność fizyczną:

Bo przydą trwogi albo potrzeby jakie, jakoż świat bez tego być nie może, już siła będziesz miał przed onym chwastem, co ni koniczka osieść, ni drzeweczka w rękę wziąć, ni zbroiczki na się włożyć nie umie, a czasem z przestrachu zadni plach na przodku sobie zawiesi, a mnima, iż tak barzo dobrze. Nuż i hetman, i każdy dzielny człowiek już cię będzie na lepszej baczności miał, wiedząc to wżdy na cię, iż to umiesz, czego drugi nie umie. [--] Już ci stąd sława, ozdoba i piękna znajomość róść i mnożyć się snadnie może ${ }^{20}$.

Narzekania Satyra z poematu Kochanowskiego zawierają diagnozę zmian społecznych, w których powstrzymanie - o czym świadczą wybory życiowe pisarza - sam nie wierzył ${ }^{21}$. Zarysowując w ostatniej pieśni Sobótki wizję arkadii ziemiańskiej, przeciwstawił szczęśliwe życie wiejskie kondycji dworaka, żeglarza dla zysku narażającego życie na morzu, prawnika za pieniądze naginającego prawdę oraz żołnierza służącego za żołd. Są to profesje ryzykowne bądź niegodne, które obok innych zajęć (np. lichwy, podróży zagranicznych, pracy umysłowej) i upodobań (np. marnotrawienia majątków na zbytkowne stroje czy wyszukane potrawy) staną się u późniejszych twórców stałymi motywami, rozwijanymi nieraz w ekskursach satyrycznych. U Kochanowskiego - podążającego oczywiście za epodą Horacego ich wyliczenie służy zbudowaniu opozycji przeciwstawiającej enklawę

$19 \mathrm{Tu}$ i dalej elegię cyt. za edycją: J. Kochanowski, Elegiarum libri quattuor, ed. critica commentata a cura di F. Cabras, Firenze 2019; przekład polski za: idem, Z tacinsska śpiewa Stowian Muza. Elegie, foricenia, liryki, tł. L. Staff, wstęp Z. Kubiak, Warszawa 1982, s. 123.

${ }^{20}$ M. Rej, Żywot cztowieka poczciwego, oprac. J. Krzyżanowski, Wrocław 1965, s. 377-378: II 17, 4 (por. I 9, 2-4); zob. też L. Szczerbicka-Ślęk, W kręgu Klio $i$ Kalliope. Staropolska epika historyczna, Wrocław 1973, s. 142-143.

${ }^{21}$ Nie mogę przystać na opinię K. Koehlera (Jakie poglady religijne mógt mieć Jan Kochanowski? Kilka uwag na marginesie lektury "Zgody”, „Satyra” i „Wróżek", w: idem, Rzeczpospolita, obywatelskość, wolność. Szkice o polskim pisarstwie politycznym XVI wieku, Warszawa 2016, s. 158-159), który pisząc o Satyrze, z obawy, by pisarza nie uznać za osobę dwulicową, skłonny jest uznać, że poglądy zawarte $\mathrm{w}$ tym publicystycznym i inspirowanym przez patronów autora tekście odpowiadały jego własnym. 
szczęścia i życia moralnego światu zewnętrznemu ${ }^{22}$. Nic poeta nie wspomina o służbie wojennej w obronie ojczyzny, dla sławy, gdyż zburzyłoby to idealizowane wyobrażenie. W elegii III 14 ostro zganił wojenne zapały panujące wśród ludzi, łącząc je z niskimi pobudkami (chciwością, okrucieństwem), negując też wiarę w to, że bohaterstwo na polu bitwy zapewnia życie wieczne. $\mathrm{O}$ wiele bardziej cenił postawę pacyfistyczną. Mówiąc o własnych wyborach, opowiada się za spokojnym gospodarzeniem na ojcowiźnie, gdzie chętnie wysłucha opowieści zbłąkanego żołnierza. Chwaląc wieś w elegii III 15, nadmienia jednak:

Hinc miles patiens aestus et frigoris aeque,

Hinc rigidus consul venit ad imperium ${ }^{23}$.

(w. 21-22)

W dystychu tym wieś, ale rzymska wieś, potraktowana została zgodnie z antycznym przekonaniem jako miejsce, skąd wywodzą się najlepsi żołnierze ${ }^{24}$. Poeta przypomina także postać Lucjusza Kwinkcjusza Cyncynata, który wedle legendy podczas wojny powołany został przez senat na urząd dyktatora, gdy wykonywał prace polowe. Obie wstawki erudycyjne pełnią w elegii funkcje laudacyjne, stanowią argumenty w pochwale miejsca jako takiego, nie polskiej wsi.

W poezji czarnoleskiej tendencja jest wyraźna. Utwory opiewające ziemiańską arkadię negują wartości żołnierskie jako sprzeczne

22 Omawiana opozycja będzie się oczywiście powtarzać w kolejnych parafrazach rzymskiego wiersza: Stanisława Mińskiego, Sebastiana Petrycego, Samuela Twardowskiego, Jana Libickiego czy Wespazjana Kochowskiego, utrwalając antynomiczne ujęcie. Z utworów zachwalających ziemiańską sielankę wedle paradygmatu sobótkowego chyba tylko Hieronimowi Morsztynowi udało się włączyć w rejestr wiejskich radości służbę wojskową: „I kupa synów ojca namniej nie frasuje, / Gdy z nich ma swe pociechy. Snadź i radość czuje, / Gdy na pierworodnego cnotę, męstwo sławę / Patrzy tatuś szedziwy, a on już buławę / Nad rycerską drużyną otrzymał, skąd jego / Zna posługi ojczyzna, zna i przeważnego / Animuszu dzielności [--]”, idem, Światowa Rozkosz z ochmistrzem swoim i ze dwunasta swych stużebnych panien, w: idem, Wybór poezji, wstęp i oprac. R. Grześkowiak, Wrocław 2016, s. 288: w. 183-189. Pamiętać jednak należy, że cykl ten „jest przykładem upodrzędnienia żywota ziemiańskiego wobec idei vanitas”; A. Karpiński, op. cit., s. 39.

23 „Stąd żołnierz wśród upałów i wśród mrozów zdrowy / i stąd też konsul doszedł do władzy surowy”.

24 Zob. komentarze wydawców: J. Kochanowski, Carmina Latina. Poezja tacińska, t. 3: Komentarz, oprac. Z. Głombiowska, Gdańsk 2013, s. 660-661; idem, Elegiarum libri quattuor, s. 571-572. 
z obranym ideałem egzystencjalnym. Stając przed tą alternatywą, późniejsi autorzy nie zawsze zgadzali się z kategorycznym stanowiskiem Kochanowskiego.

Jednym z pierwszych rymopisów podążających śladami pionierów nurtu ziemiańskiego był niezamożny szlachcic Andrzej Zbylitowski, który po nieudanych próbach znalezienia protektora osiadł na wsi. Literackim świadectwem tej decyzji są dwa poematy: Żywot szlachcica we wsi (1597) oraz Wieśniak (1600). W obu przeciwstawił autor wojaczkę egzystencji ziemiańskiej. Kreując się na prostaczka, w pierwszym z nich ujmował tę opozycję jako wynik wyboru:

Bo ja nie myślę, żebym tureckie zawoje miał rąbać i szykować do potrzeby boje.

[--]

Wolę patrzyć na pługi, kiedy ciągną w pole,

i na brony, którymi uprawują role, niż na działa straszliwe abo nawę zbrojną, bo te szkody, a owe rozkosz dadzą hojną ${ }^{25}$.

(w. 173-174, 181-184)

Opowiadając się za wyższością obranej kondycji ${ }^{26}$, dowodzi Zbylitowski dalej również, skądinąd słusznie, że bez dostarczającej żywności gospodarki rolnej „za fraszki by stały i wojska ogromne, / i zamki niedobyte, i miasta obronne" (w. 449-450) ${ }^{27}$. Jest to oczywiście argument przemawiający na korzyść prowadzenia folwarku, choć można w nim dopatrywać się także usprawiedliwienia. Nie przeszkodziło to pisarzowi włączyć się w tym samym utworze w nurt publicystyki

25 Tu i dalej utwory poety cyt. za: A. Zbylitowski, Wiersze zebrane, oprac. A. Kochan, teksty łac. tł. i oprac. E. Żybert-Pruchnicka, Warszawa 2018; por. też Wieśniak, w. 59-68, 83-86.

26 Programowy charakter utworu wskazał twórca bardzo wyraźnie już w pierwszych słowach, trawestując incipit Eneidy. Wergiliuszowe „Arma virumque cano” zmienił na „Żywot pobożny śpiewam” (w. 1), składając tym samym jednoznaczną deklarację ideologiczną; zob. A. Krzewińska, op. cit., s. 67-68; A. Karpiński, op. cit., s. 57, 178.

27 W przedmowie J. Siebeneichera do Gospodarstwa Gostomskiego (idem, op. cit., s. 8) przytoczona została podobna myśl autora poradnika: „Dobre żołnierstwo, dobry dwór, ale pług w domu jeśli go nie wspiera, słabo barzo iść musi, chyba żeby mu fortuna łaską jaką osobliwą z nieba poświeciła”. 
strofującej szlachtę za odejście od rycerskich tradycji stanowych. Nawiązując do Satyra Kochanowskiego ${ }^{28}$, narzeka Zbylitowski na porzucenie chlubnych wzorców i jałowe sejmowanie, by konkludować apelem: „Najdźcie wżdy obronę, / którą byście zachować mogli tę Koronę" (w. 149-150). Łatwo spostrzec, że autor próbował zespolić wątki myślowe z poezji czarnoleskiej, które u poprzednika występowały w utworach o odmiennym przeznaczeniu. W partiach publicystycznych wchodził $\mathrm{w}$ rolę moralizatora politycznego, w partiach afirmujących żywot ziemiański odniósł się do własnych wyborów egzystencjalnych, pozostających w sprzeczności z etosem ojców.

Ów etos przeniknął też, lecz na innych zasadach, do Wieśniaka. Zachwalając zimowe rozrywki, prócz polowania przewidział autor czas na lekturę. W obszernym passusie pojawia się repetycja wątków z mitologii antycznej (w. 247-320), bardzo oględnie wskazał autor na zaciekawienie historią wojen starożytnych (w. 322-332), by w końcu w kilkuset wersach (w. 333-648) przedstawić ujętą w formę katalogu władców panoramę dziejów ojczyzny, poczynając od Lecha i Kraka, a na Stefanie Batorym kończąc. Zgodnie z tradycją tego rodzaju twórczości, wyliczając kolejnych władców w porządku chronologicznym, zaprezentował autor zarówno ich zalety oraz dokonania, jak i wady, tak aby całość złożyła się na swego rodzaju zwierciadło panującego ${ }^{29}$. W przypadku zasług nie pomijał oczywiście czynów militarnych, chwaląc np. Zygmunta Starego czy Stefana Batorego za zwycięstwa moskiewskie. Dzięki takiemu zabiegowi ziemianin Zbylitowskiego zdaje się uświadamiać sobie, że poza arkadią toczy się historia, w której obowiązują inne reguły. W tym równoległym świecie ucieleśniane przez kolejnych monarchów ideały rycerskie pozostają aktualne, lecz tytułowy bohater woli je poznawać jedynie z kart kronik ${ }^{30}$. Jest to zgodne ze stanowiskiem wyrażonym w Żywocie szlachcica.

28 Nawiązanie sygnalizuje autor bezpośrednio - w. 123: „Dalekośmy się od swych przodków odrodzili” stanowi powielenie zarzutu z Satyra (w. 43): „Dalekoście się od swych przodków odstrzelili”, J. Kochanowski, Poematy okolicznościowe, oprac. R. Krzywy, Warszawa 2018, s. 169.

29 Zob. R. Krzywy, Poezja staropolska wobec genologii retorycznej. Wprowadzenie do problematyki, Warszawa 2014, s. 73-84.

30 Inaczej katalog władców w Wieśniaku zinterpretowała L. Szczerbicka-Ślęk (eadem, op. cit., s. 144). Badaczka uważa, że poeta potraktował w nim „przeszłość jako belle epoque, która już bezpowrotnie minęła, ale dla której wciąż żywił podziw”. Sąd ten powtarza A. Kochan w pracy Arkadia Andrzeja Zbylitowskiego. Uwagi do „Żywota szlachcica we wsi” i „Wieśniaka”, w: Staropolskie Arkadie, red. J. Dąbkowska-Kujko, J. Krauze-Karpińska, Warszawa 2010 (Studia Staropolskie. Series 
W kolejnej wypowiedzi zalecającej ziemiańską idyllę, opublikowanych w roku 1618 Zabawach orackich Stanisława Słupskiego, motywy militarne pojawiają się marginalnie. Autor bodajże jako pierwszy tak wyraźnie dokonał transpozycji w mityczne czasy przodków afirmowanego modelu, przeciwstawiając pracę na roli współczesnemu zajmowaniu się przez szlachtę handlem:

Przodkowie naszy w rolej się kochali,

A o kontraktach [tj. jarmarkach], jak dziś, nie słychali,

A mieli wszytko, wszytkiego gwałt było,

Dostatek wszelki, pojźrzeć było miło ${ }^{31}$.

(w. 41-44)

W zakończeniu utworu Słupski przekonuje, że gdyby nadal podążano za wzorami ojców zamiast wydawać pieniądze na zbytki, kraj opływałby we wszelkie dostatki, „byłoby za co walczyć i budować” (w. 503). Jest to oczywiście polemika z Satyrem Kochanowskiego. W poemacie poprzednika przekwalifikowanie się szlachty potraktowane zostało jako przyczyna niedomogów obronności państwa. Autor siedemnastowieczny skorygował tę nieracjonalną opinię leśnego bożka, źródeł zła upatrując w odejściu od złotego umiaru ojców oraz marnotrawieniu bogactw.

Zauważyć trzeba, że Słupski w ogóle nie brał pod uwagę bojowego potencjału stanu, z którego się wywodził. Jest piewcą pokoju w ogólności, twierdząc, że „lepszy go [chleba] kęs najmniejszy w pokoju, / niźli marcypan w trwodze abo w boju” (w. 109-110), a jako jeden z argumentów pochwały szczęśliwego bytowania „oracza” pisarz wskazuje to, że nie myśli on o wojnach (w. 74). I w tym przypadku zatem świat rycerskich powinności został usunięty poza wiejską arkadię, która w ujęciu skromnego twórcy stanowi rodzaj etycznego depozytu odziedziczonego po przodkach, niweczonego przez odejście od dawnych pryncypiów (zwłaszcza poprzestawania na małym).

Nova, t. 29 [85]), s. 244. Czasy Stefana Batorego nie należały z pewnością dla rymopisa do odległej przeszłości. Także poprzedzająca poemat dedykacja dla księcia Janusza Ostrogskiego uznaje rangę zasług wojennych adresata.

31 Tu i dalej utwory Słupskiego i Jeżowskiego cyt. za: S. Słupski, Zabawy orackie (1618) / W. S. Jeżowski, Oekonomia (1638), wyd. J. Rostafiński, Kraków 1891. W przytoczeniach modernizuję przestankowanie. Nadmienić należy, że już w pieśni „Spokojny kąt komu Bóg dał i myśl spokojną...” omawiany ideał zdawkowo sytuowany był w przeszłości: „Piękny ono wiek stary, gdzie dwie jarzmie wołów / dawały wszystkę żywoność bez przyprawnych stołów”, cyt. za: S. Kot, op. cit., s. 35, w. 5-6. 
Utwór Słupskiego stał się podstawą amplifikowanej przeróbki pióra Władysława Stanisława Jeżowskiego, który w roku 1638 opublikował Ekonomije albo Porzadek zabaw ziemiańskich, wydaną ponownie w nieco poszerzonej redakcji dekadę później. Jest to świadectwo zarówno popularności twierdzeń zawartych w Zabawach orackich, jak i ich utrwalania. Powtórzył autor, a nawet nieco wzmocnił twierdzenia o zamiłowaniu przodków do pracy na roli, wprowadził silne akcenty antymieszczańskie i antyżydowskie. Zmiana dotyczy także stosunku do spraw rycerskich, co daje się zauważyć już w wypowiedziach ramowych. O ile Słupski jedynie w wierszu na herb Radwan wspomniał o wojennych zasługach protoplasty rodu Cikowskich, mającego za Bolesława Chrobrego wsławić się w bitwach z Rusinami, w skierowanym zaś do podkomorzego krakowskiego Stanisława Cikowskiego liście dedykacyjnym nader oględnie wzmiankował o zasługach wojennych dziada adresata, walczącego $\mathrm{w}$ armiach ostatnich dwu Jagiellonów ${ }^{32}$, o tyle Jeżowski zarówno w utworze stemmatycznym na herb Jelita, jak i w rymowanej dedykacji dla Stanisława Prumieńskiego odwołał się w pochwale rodu do typowo rycerskich kategorii etycznych (męstwo, rozwaga, nieśmiertelna sława) oraz bitewnych zasług jego przedstawicieli, chwaląc adresata oraz jego syna Jana za udział w walkach w obronie ojczyzny. Zmiana jest bardzo widoczna: u Słupskiego rycerskie przewagi antenatów patrona nie są eksponowane, sytuuje się je w przeszłości, dla Jeżowskiego militarna aktywność przedstawicieli stanu pozostaje czymś naturalnym i koniecznym. Przekonuje też o tym tekst główny.

Stwierdziwszy, że „mieszczanie i żydzi wioski szlacheckie podrożyli"33, to jest doprowadzili przez spekulacje do wzrostu cen wiosek i pauperyzacji szlachty, zmuszając ją w opinii autora do przenosin „cudzoziemskim zwyczajem” (w. 348) do miast, w następujący sposób tłumaczy Jeżowski spadek obronności kraju:

W Polsce dlatego szlachty do popisu mało,

W województwach ich przez to siła zubożało,

Przebrało się tych czasów ochotnych do boju,

By męstwem zachowali ojczyznę w pokoju.

Nie prosili przodkowie żadnych cudzoziemców

32 Mowa o kasztelanie bieckim Stanisławie (zm. 1576), który zasłużył się zwłaszcza w wojnach moskiewskich za Zygmunta Augusta; zob. S. Bodniak, Cikowski Stanistaw, PSB, 4, 1938, s. 72-73.

33 Nota marginesowa do w. 827. 
Ani też zaciągali do pomocy Niemców,

Sami zawsze potężnie znaczny odpór dali,

Tacy bracia odważni przed laty bywali.

(w. 349-356)

W ten oto sposób udało się Jeżowskiemu pogodzić oba etosy. Uzasadniał je tradycją odziedziczoną po przodkach, a za naruszenie starego porządku obwinił panoszące się nadmiernie warstwy niższe. Jak sądzę, przyświecał pisarzowi zamiar skorygowania oburzającego dlań stanowiska poprzednika, którego utwór postanowił przenicować.

Niewykluczone, że pojawiający się w Ekonomii antagonizm klasowy to wynik znajomości wcześniejszego poematu, ogłoszonego w roku 1620 Bytu ziemiańskiego i miejsckiego Józefa Domaniewskiego „gwoli szlacheckiej niewieście, / co pragnęła mieszkać w mieście" (k. $\mathrm{A}_{1}$ ver. $)^{34}$. Autor zamierzał wykazać wyższość życia wiejskiego, by skłonić modelową adresatkę do zaniechania przenosin. Cel ten implikował dobór pochodzących z najrozmaitszych porządków argumentów. Przypominając etymologię nazwy „Polska” wyprowadzaną od „pola” (k. $\mathrm{B}_{1}$ ver.), pisarz uznał żywot wiejski za właściwy całemu narodowi, a także ustanowiony przez Stwórcę, czego dowodził powołaniem się na Księgę Rodzaju. Stwierdził mianowicie, że sam Bóg przeznaczył ludzi do pracy na roli, gdyż wsie istniały, zanim zaczęto zakładać miasta $\left(\mathrm{k} . \mathrm{C}_{4} \text { ver. }\right)^{35}$. Co więcej, ich powstanie doprowadziło zdaniem autora do wojen, ponieważ wzniesione przez ludzi o nieczystych sumieniach, skłaniają innych do podbojów. Przeciwstawił im mieszkańców wsi, nieusposobionych jakoby wojennie (k. $\mathrm{D}_{1}$ rec.-ver.), przekonując dalej, że żadna obrona nie pomoże, jeśli Stwórca zdecyduje inaczej (dowodzić tego ma upadek wielu miast biblijnych). Konkluzja mogła być tylko jedna:

I darmo się przechwalają

Rycerze, kiedy nam bają,

Jakoby nas bronić mieli

Od naszych nieprzyjacieli.

$[--]$

A iż podczas wygrawają

I zwyciężcami zostają,

Racyja: Bóg tak uradził,

Aby przez to złych zagładził.

$$
\text { (k. D } 3 \text { ver.) }
$$

4 Utwór cytowany za pierwodrukiem: Lubcz 1620.

35 Myśl ta pojawiła się wcześniej u Kochanowskiego i Zbylitowskiego; zob. A. Karpiński, op. cit., s. 148-149. 
Ta kaznodziejska sofistyka wydaje się oderwana od rzeczywistości ${ }^{36}$, choć oczywiście pozostaje w zgodzie ze światopoglądem religijnym. Ariański pisarz zdaje się odrzucać - zgodnie z pacyfistyczną orientacją wyznania, charakterystyczną dla początkowych dekad XVII w. ${ }^{37}$ militarne zobowiązania stanu, uznając wojny za wynik ludzkiego zepsucia bądź narzędzie w rękach Boga ${ }^{38}$.

Inny arianin, Zbigniew Morsztyn, odmówił służbom marsowym wartości z zupełnie innych przyczyn. Zaznawszy w młodości trudów wojennych w szeregach wojsk Bogusława Radziwiłła, zdecydował się osiedlić na wsi, by wieść żywot ziemiański. Poetyckim świadectwem tego wyboru jest autobiograficzna Pieśn wyrażająca $w$ sobie wszelakie sposoby życia na tym świecie i ukazująca, w czym największe szczęście cztowiecze nade wszystko zawiera się (znana też pod tytułem Votum ... de primo genere vitae), datowana na lata 1657-1659. Utwór nie był wówczas drukowany, zachował się w kilku odpisach. Poniekąd zapowiada go wierszowany List do Imci Pana Aleksandra Mierzeńskiego $\mathrm{z}$ roku 1655 , w którym po realistycznych scenach wojennych dał autor wyraz swemu pragnieniu zaznania sielskich szczęśliwości ${ }^{39}$. Nie jest to jednak jeszcze wypowiedź programowa, jaką stało się Votum.

Morsztyn konstatuje na wstępie tego poematu niedoskonałość rodzaju ludzkiego, który od młodości ulega zgubnym powabom świata. Pragnąca kontaktu ze Stwórcą dusza po przebudzeniu z tego letargu uświadamia sobie marność doczesności i swój prawdziwy cel. Poeta daje do zrozumienia, że i w nim dojrzały takie myśli, dlatego żegna się ze starym życiem światowym, oznaczającym w jego przypadku trudnienie się wojaczką, by zaznać ziemiańskiego spokoju:

Nic mi po broni, nic po boju chciwym,

Który mnie nosił, koniu natarczywym,

36 Podobnie w ustępie omawiającym niedogodności życia miejskiego, w którym Domaniewski pisze o przymusie zapewniania gospody żołnierzom dopuszczającym się rozmaitych swawoli (k. A 4 rec.-ver.). Nic nie wspomina natomiast o stacjach czy grabieniu wsi.

37 O kształtowaniu się poglądów braci polskich na temat obowiązku służby wojskowej zob. J. J. Kolarzowski, Idea praw jednostki w pismach braci polskich. U narodzin nowożytnej koncepcji praw cztowieka, Warszawa 2009, s. 118-130.

38 Co znamienne, pisząc o szlacheckich powinnościach, ogranicza je do służb cywilnych (k. B ${ }_{4}$ ver.): „Nie omieszkiwa na zjazdy, / Na sejmiki i na sejmy / Jako miłośnik uprzejmy / Ojczyzny, a dla tej sprawy / Może nabyć dobrej sławy”.

39 Zob. J. Pelc, Wstęp, w: Z. Morsztyn, Wybór wierszy, oprac. J. Pelc, Wrocław 1975, s. XLIII; przytoczenia według tej edycji. 
Już na złe ludzkie wymyślone sztuki,

Strzały i łuki,

Pancerz, karwasze, buzdygan, wsiędzenie,

Wszystek rynsztunek powieszę na ścienie,

A na kopijej, jak na własnej grzędzie,

Kokosz usiędzie.

(w. 165-172)

Dalsza część obszernego poematu składa się z dwóch części. W pierwszej skrupulatnie wyliczył Morsztyn wszelakie przejawy żołnierskiej nędzy: głód, choroby, mróz, deszcz, skwar, dojmujące pragnienie, strach przed śmiercią, niewolę, brak wynagrodzenia za służbę. Zapamiętał także dopuszczanie się grabieży, którym towarzyszyły lamenty krzywdzonych, a nawet torturowanych chłopów, co wywołuje w nim obawę zarówno o zbawienie własne, jak i współtowarzyszy $^{40}$. Nie ulega wątpliwości, że autor na podstawie własnych doświadczeń rewiduje mit rycerski zarówno w jego aspekcie heroicznym, jak i religijnym. Odpowiedź na to rozgoryczenie zawiera druga część utworu, przedstawiająca wizję arkadii ziemiańskiej jako wynik poszukiwania optymalnego modelu egzystencji ${ }^{41}$. Jest to arkadia jeszcze nie doświadczona, lecz wyobrażana (autor pisze w wersach 361-362: „Prawdać, że mi się jeszcze nie dostało / gospodarować, tylko się widziało"), stąd też przedstawia ją autor zgodnie z ustalonymi wzorcami literackimi, sygnalizując to bezpośrednimi nawiązaniami do Sobótki Kochanowskiego (por. np. w. 585-588) ${ }^{42}$. Trzeba dodać, że swego celu dopiął. Po banicji arian znalazł upragniony azyl w Prusach Książęcych, gospodarząc w miejscowościach Rudówka i Jagodne Małe ${ }^{43}$.

40 Nie budzi u niego natomiast obaw sam udział w wojnie, co zdaje się świadczyć o odchodzeniu arian w niektórych kręgach od restrykcyjnego pacyfizmu, o czym pisze J. J. Kolarzowski (idem, op. cit., s. 125-128). Odmienny sąd sformułowała A. Krzewińska (eadem, op. cit., s. 72), która uważała, że negacja ideałów rycerskich w Votum podyktowana była ariańskim pacyfizmem Morsztyna.

41 Zob. L. Szczerbicka-Ślęk, op. cit., s. 144-146.

42 Zwraca się uwagę, że o ile ukazując wieś, używa Morsztyn konwencjonalnych środków i obrazów, o tyle gdy „pisze o życiu żołnierza, nie operuje ogólnikami, lecz tworzy, na podstawie własnych doświadczeń, przejmujące swoim realizmem i okrutną rzeczywistością wojny obrazy”; A. Karpiński, op. cit., s. 134.

43 W ofiarowanej żonie Kolędzie napisanej w Królewcu ... 2 stycznia 1674 dał Morsztyn wyraz zadowolenia ze zdobytej stabilizacji, twierdząc, że choć skromna, pozwoliła osiągnąć szczęście i wyzwoliła od dopustów losu. 
Morsztyn w Votum nie dążył do żadnych kompromisów, uzgadniając fakty z własnej biografii z sytuacją wyboru między konkurencyjnymi modelami życia, którego pozaziemski cel jest w jego odczuciu jasno określony przez chrześcijański dualizm. Prowadzi to do całkowitej dezawuacji mitu rycerskiego. Żywot ziemiański uznany został za najlepszy z możliwych, by dotrzeć do niebiańskiej ojczyzny, choć w opisie ziemiańskich zajęć i przyjemności ów cel nadrzędny zdaje się jednak ustępować pragnieniu zaznania szczęścia doczesnego. Gwoli prawdy wspomnieć jednak należy, że wybór własnej drogi nie skłonił go do zaprzestania sławienia męstwa wojennego, o czym świadczą takie utwory, jak Stawna wiktoryja nad Turkami [--] pod Chocimiem otrzymana (1673) czy Duma o wzięciu szturmem Pawtoczy (1675). Nie dowodzi to oczywiście chwiejności sądu autora, lecz stosowania odmiennych kryteriów w refleksji osobistej i twórczości przeznaczonej do publikacji (Stawna wiktoryja) bądź dla możnego protektora (Duma).

Badane zagadnienia znalazły również odzwierciedlenie w Morskiej nawigacyi do Lubeka Marcina Borzymowskiego, rzadko rozpatrywanym w kontekście ideologii ziemiańskiej poemacie epickim opublikowanym w roku 1662, przedstawiającym przebieg bałtyckiej żeglugi odbytej jedenaście lat wcześniej. O autorze niewiele wiadomo. Przypuszcza się, że był synem Wojciecha, wziętego malarza, który wykonywał zlecenia m.in. dla Zygmunta III ${ }^{44}$. Utwór zadedykowany został Janowi Zamoyskiemu Sobiepanowi oraz wdowie po Jeremim Wiśniowieckim, Gryzeldzie Konstancji z Zamoyskich, jakkolwiek dworzaninem Zamoyskich poeta raczej nie był - podejrzewa się jego związki z Wiśniowieckimi ${ }^{45}$.

W eposie morze zostało ukazane jako przestrzeń wroga ludziom, narażająca ich na niebezpieczeństwo oraz wymagająca ciagłej opieki sił nadprzyrodzonych (Boga, Maryi, św. Anny). Zatrważającym sztormom, oddaleniu od bezpiecznego lądu i nużącym umysł jednostajnym widokom przeciwstawił Borzymowski przyjemności, których może doświadczać zwykły wędrowiec. Nieprzypadkowo zaliczył do nich sielski obrazek nawiązujący wyraźnie do fragmentu pieśni Panny XII z cyklu sobótkowego:

44 Zob. R. Leszczyński, Marcin Borzymowski na Lubelszczyźnie, „Prace Polonistyczne", 23, 1967, s. 102-104.

45 Zob. ibidem, s. 110. 
Idzieli przez las: ptaszkowie swe pieśni

I faunowie wykrzykują leśni,

Pasterze bydło pasą nad łąkami

Przegrawając się z sobą piszczałkami;

Wszędzie są trawy, a na nich wierzgają

Konie albo się barani tryskają ${ }^{46}$.

Fragment ten zapowiada znamienny epizod: po gwałtownej burzy podróżnicy dopływają do wyspy. Twórca przedstawił ją zgodnie z wyobrażeniami o ziemiańskiej arkadii. W obszernym passusie (II, w. 401-534) roztoczył przed czytelnikiem wizję krainy wiecznej wiosny i lata, w której dzika przyroda płynnie łączy się z motywami pasterskimi i georgicznymi. Fikcjonalność miejsca oraz jego idylliczny charakter uzmysławiają, że nie werystyczna relacja z podróży stanowiła o głównym zamyśle Borzymowskiego, lecz afirmacja określonych wartości. Opis wyspy oraz zajęć gospodarskich uznać należy za konwencjonalny sposób powiadomienia o właściwym dla człowieka środowisku, które kontrastować ma przede wszystkim z grozą morza. Nie utyskuje natomiast poeta na niedogodności życia miejskiego, wręcz przeciwnie $-\mathrm{w}$ dalszych partiach utworu pobyt $\mathrm{w}$ najprawdopodobniej zmyślonym Stokhopie, a następnie w Rostocku traktuje jako sposobność do zaprezentowania wzorcowych relacji międzyludzkich: więzów rodzinnych, miłości małżeńskiej, gościnności, biesiad, stosownych rozrywek towarzyskich itp. Odnosi się wrażenie, że sobótkowe „wieśne wczasy i pożytki”, nawet przy uwzględnieniu symboliczności czarnoleskiej refleksji o człowieku, okazały się nie wystarczać Borzymowskiemu do zarysowania godnego uznania ideału egzystencjalnego. Uczuciom łączącym męża i żonę, nadmienić też należy, przeciwstawił w ostatnim rozdziale grzeszną relację Arnolfa i Praksedy, współtowarzyszy podróży, których występek Bóg pokarał kolejną nawałnicą. Ukazane zgodnie z poetyką romansową dzieje występnej miłości służą oczywiście - jak inne sytuacje przedstawione w eposie - parenezie per exempla.

Od głównej linii fabularnej odbiega dygresja narracyjna wypełniająca prawie cały rozdział czwarty, najobszerniejszy w całym poemacie. Traktuje on o natrafieniu przez podróżników na płynącego do Lubeki kasztelana chełmińskiego Zbigniewa Gorajskiego (w rzeczywistości senator zmierzał do miasta lądem, więc spotkanie na morzu jest

46 M. Borzymowski, Morska nawigacyja do Lubeka, oprac. R. Pollak, Gdańsk 1971, s. 57: II, w. 19-24. 
konstrukcją literacka $)^{47}$, który zrelacjonował rodakom przebieg bitwy pod Beresteczkiem. Opowiadanie o czynach wojennych poddano zabiegom heroizacyjnym, eksponując marsowe czyny zarówno króla oraz wybitnych wojowników, jak i całej walczącej pod komendą Jana Kazimierza zbiorowości. Zwłaszcza gesta Wiśniowieckiego i Zamoyskiego wyróżnił poeta, ukazując ich jako pomagających sobie na polu bitwy przyjaciół ucieleśniających zalety rycerskie. Stronę polską wspiera w zmaganiach Bóg, przeciwników - moce piekielne. Nie ulega wątpliwości, że celem dygresji jest afirmacja ideału osobowego obowiązującego podczas wojny, tak jak pozostałe rozdziały prezentowały wzorzec aktualny w okresie pokoju. Nie można zgodzić się z opinią Rafała Leszczyńskiego, który uważa, że obszerny passus militarny psuje kompozycję Morskiej nawigacyi do Lubeka, służąc jedynie pozyskaniu względów Jana i Gryzeldy Zamojskich ${ }^{48}$. Bliższy prawdy jest z pewnością Edmund Kotarski, który dostrzegł komplementarne potraktowanie obu etosów przez Borzymowskiego ${ }^{49}$. Ich uzgodnienie w dziele epickim służyć miało niewątpliwie usankcjonowaniu opiewanych wzorców oraz szlacheckiej parenezie stanowej.

Odmiennie omawiany problem został ujęty w Transakcyi wojny chocimskiej Wacława Potockiego, obszernym eposie historycznym, którego pierwsza redakcja ukończona została w grudniu 1670 r. Uznając te same pryncypia co Morsztyn i Borzymowski, autor inaczej jednakże określił relacje między oboma etosami. Ze względu na rangę dzieła i brak studium syntetycznie traktującego omawianą problematykę w epickiej wizji Potockiego warto poświęcić poematowi więcej uwagi.

47 Zob. D. Kupisz, Zbigniew Gorajski (1596-1655). Studium z dziejów szlachty protestanckiej $w$ Matopolsce $w$ pierwszej potowie XVII wieku, Warszawa 2000, s. 115-116. Drogą morską podróżował starosta mitawski Jerzy Fiszer, jeden z komisarzy wyznaczonych do rokowań w Lubece.

48 Zob. R. Leszczyński, op. cit., s. 113.

49 Por.: „I pejzaż idylliczny, i pejzaż heroiczny zostały przeciwstawione rzeczywistości morskiej. Czyn rycerski spotkał się z aprobatą jak świat ziemiański, wiejski. Między wiejskim stylem życia a modelem rycerskiego postępowania nie dopatrzył się autor zasadniczej kolizji. Za obcy uznał żywioł morski. Opozycja zarysowała się między rzeczywistością rustykalną i rycerską a egzystencją w środowisku morskim", E. Kotarski, Sarmaci i morze. Marynistyczne początki w literaturze polskiej XVI-XVII wieku, Warszawa 1995, s. 136-137. W omówieniu korzystam również ze wstępu Romana Pollaka do cytowanego wydania oraz z własnej interpretacji utworu: R. Krzywy, Od hodoeporikonu do eposu peregrynackiego. Studium z historii form literackich, Warszawa 2001, s. 229-242. 
W utworze sięgnął Potocki do wydarzeń sprzed półwiecza, by przedstawić współczesnym pokolenie dziadów i ojców jako służący celom parenetycznym wzorzec męstwa i poświęcenia dla ojczyzny. Można oczywiście ów deklarowany wprost program dzieła uznać za apel motywowany narastaniem konfliktu z państwem tureckim, który doprowadził rychło do kolejnej bitwy pod Chocimiem, lecz byłoby to daleko idącym uproszczeniem. Autor zbyt wiele wysiłku twórczego włożył w opracowanie tematu, by ograniczać jego zamiary jedynie do celów ekshortacyjnych. Obraz walczących z armią Osmana II w 1621 r. uzgodnił Potocki z wyobrażeniami o odziedziczonych po sarmackich przodkach wzorcach osobowych, a ich ucieleśnienie dojrzał w szlachcie zgromadzonej w obozie Jana Karola Chodkiewi$\mathrm{Cza}^{50}$. Wyobrażenia te konsekwentnie są w poemacie przeciwstawiane obyczajom własnych czasów, prezentowanych $\mathrm{z}$ wyraźną intencją satyryczną:

Nie łoże, nie łabęcie mchy, nie miękkie szaty

Przodki nasze a stare zdobiły Sarmaty.

Ziemia łóżko, barłóg mech - falandysz od festu.

[--] gdzie cnota rycerska nas braci,

Ani złotogłów, ani tam aksamit płaci.

Pódźże z nim do rynsztunku, najdziesz tam i krzesła [tj. siodła],

Znajdziesz i marsowego zwierciadła rzemiesła ${ }^{51}$.

(III, w. 1009-1011, 1015-1018)

Obecnym zbytkom przeciwstawił autor w cytowanym fragmencie rozpowszechniony przez twórców nowołacińskich ideał „twardego Sarmaty” (durus Sarmata) ${ }^{52}$, który traktowany był przez wielu siedemnastowiecznych ideologów stanowych jako elementarna część dziedzictwa przodków definiująca istotę szlachectwa ${ }^{53}$. Także Potocki

50 Zob. M. Kaczmarek, Sarmacka perspektywa stawy. Nad „Wojna chocimska”" Wactawa Potockiego, Wrocław 1982, s. 45-46.

51 Tu i dalej utwór cyt. za: W. Potocki, Wojna chocimska, oprac. A. Brückner, Kraków 1924.

52 Zob. J. Budzyński, Sarmackie echa w literaturze tacińskiej na Ślasku XVI-XVII wieku, w: Sarmackie theatrum, t. 1: Wartości i stowa, red. R. Ocieczek, współudz. B. Mazurkowa, Katowice 2001, s. 25-26. Mający proweniencję antyczną stereotyp bywał przez autorów obcych identyfikowany z barbarzyństwem, „potomkowie" Sarmatów wydobywali z niego cechy pozytywne; zob. T. Mańkowski, Genealogia sarmatyzmu, Warszawa 1946, s. 34-35.

53 Jeden z moralistów instruował: „Synów dobrych rodzin powinno się wysyłać do obozów, aby u boku wodzów uczyli się żołnierki, znoszenia trudów, by 
stwierdzał wyraźnie, że wszyscy „okryci / przywilejem szlachectwa” (II, w. 486-487) powinni je potwierdzać na placu boju. Podtrzymywał tym samym stanowczo aktualność wzorca.

Jednocześnie jednak poeta konfrontował ów wzorzec z ziemiańskim modelem egzystencjalnym. Z jednej strony dostrzegł rozdźwięk między obowiązkami rycerskimi a preferowaną przez szlachtę formą zarobkowania. Przedstawiając mobilizację pospolitego ruszenia w roku 1621, łaskawie pominąwszy jej efekty, stwierdził:

Jeszcześmy, jeszcze byli nie zgospodarzeli,

Żebyśmy się tak słusznej wojny wzdrygać mieli.

(II, w. 491-492)

Słowa te odnoszą się do nie tak odległej, choć idealizowanej przeszłości i zdają się zawierać przytyk do całkiem już „zgospodarzałych” współczesnych. Z drugiej jednak strony w dygresjach głosi Potocki pochwałę spokojnego żywota wiejskiego. O ile występujące w początkowych księgach eposu opisy pór roku, w których wzmianki o zajęciach ziemiańskich wywodziły się z topiki tego rodzaju deskrypcji ${ }^{54}$, dają wyobrażenie o porządku uniwersalnym mającym stanowić tło dla działań militarnych, o tyle zawierające pochwałę życia ziemiańskiego ekskursy wprowadzone do przedostatniej części eposu wyraźnie rozmijają się z głównym kierunkiem parenetycznego zamysłu dzieła.

Obszerna partia (IX, w. 385-474) zatytułowana w nocie marginesowej „Żywot spokojny” kataloguje zajęcia wiejskie zapewniające szczęśliwą a dostatnią egzystencję. W powiązaniu z porządkiem natury wylicza autor pasterstwo, rolnictwo, rybołówstwo, bartnictwo i myślistwo jako zatrudnienia uczciwe i pożyteczne. Podsumowuje jednakże ten pełen aprobaty przegląd wizją czuwającego nad księgami mędrca, który na pytanie, czego się doczytał, „rzekłby, że wszytko próżnośc” (IX, w. 466). Owa kategoryczna puenta wprowadza biblijny dystans do tego rodzaju pochwał, lecz ich nie unieważnia. Przekonuje o tym następujący zaraz ustęp opatrzony adnotacją „Żywot niespokojny" (IX, w. 475-528). Zestawił w nim twórca zachowania niegodne szlachcica: wycieranie dworskich progów w nadziei na urząd, trwonienie rodzinnych majątków, by zdobyć poklask tłumu, oraz

w końcu sami stać się mogli wodzami”, A. M. Fredro, Kwestia wojskowa, czyli o prawidtach wojny i pokoju dwie księgi, tł. J. Chmielewska, B. Bednarek, wstęp i przyp. M. Tracz-Tryniecki, Warszawa 2015, s. 261.

54 Zob. R. Krzywy, Poezja staropolska wobec genologii retorycznej, s. 85-100. 
kupczenie własnym poparciem politycznym. Wynikają one zdaniem poety z wygórowanych ambicji i chciwości. Ich jaskrawą figurą stał się w zakończeniu tego passusu sułtan Osman. Spogląda Potocki na niego z pozycji mędrca, stwierdzając, że głupotą jest pędzić poddanych w objęcia śmierci, w które i tak wszystkich „każdy dzień i godzina, i minuta goni" (IX, w. 524).

Cały ten wywód podsumowuje „Wotum” (IX, w. 529-554). Narrator wypowiada się w nim w pierwszej osobie, przedstawiając własną filozofię życiową. Pogoni władców za sławą zdobywców, ich pełnemu przepychu, wiedzionemu w poczuciu bezkarności życiu, podlegającemu jednak kaprysom Fortuny, przeciwstawił Potocki skromną egzystencję ziemianina poprzestającego na ojcowiźnie i dobrach przez nią zapewnianych. Afirmuje autor życie z dala od obłudnego świata, pozwalające kierować się umiarem $\mathrm{w}$ zakresie potrzeb materialnych, cieszyć się zdobywanym bez wysiłku dostatkiem i wolnością, a także spokojem, w którym zamierza dożyć swych dni. Te pragmatyczne poniekąd zalety uzupełnia refleksja etyczna ogólniejszej natury. Jak przekonuje poeta, prowadząc żywot ziemiański, „dosyć ma na tem, / że się sam zna, z obłudnym choć się nie zna światem” (IX, w. 549-550), ponadto - w czym rozpoznać łatwo echa nauk stoików - kultywuje cnotę, „co i w grobie nie boi się straty” (IX, w. 553). Ona to chroni go przed odmianami losu, dając poczucie wyższości nad wszelakimi „fortunatami”. Szlachecką arkadię w ujęciu Potockiego określa zatem nie tylko wizja dosytu materialnego, lecz również o wiele ambitniejsze cele: poznanie samego siebie, świadome oddalenie od wielkiego świata, by trwać w cnocie ${ }^{55}$.

W tym miejscu należy postawić pytanie o wzajemne relacje pomiędzy afirmowanymi w Transakcyi wojny chocimskiej modelami egzystencjalnymi. Jeśli się nie mylę, nie ma tu konfliktu. Kreśląc epicki obraz walk sprzed półwiecza, w pełni uznawał autor obowiązki wynikające $\mathrm{z}$ rycerskiego etosu stanowego (sam zresztą wywiązywał się z nich w młodości, zasłużywszy się choćby pod Beresteczkiem). Przypomnienie bitwy pozwala skonstruować upokarzające zwierciadło dla współczesnych, którzy odeszli - jak uważał - od chwalebnych wzorców. Ich pochodzenie nie podlega dla poety wątpliwości: stanowity one dlań dziedzictwo sarmackie. I chociaż wojnę uznawał Potocki za wynik wypaczonych ambicji, zjawisko niegodne rozumu, to jednak traktował

55 Nie można nie zauważyć, że poecie udało się zespolić w jednym eposie wszystkie trzy mity, o których pisał J. Huizinga. 
ją również jako trwały element funkcjonowania społeczeństw oraz sposobność do wykazania się męstwem i miłością do ojczyzny. Odnosi się nawet wrażenie, że w opisach batalistycznych autor dawał się nieraz ponieść patriotycznemu zapałowi ${ }^{56}$.

Jednakże nie ideał rycerza stanowił wedle Potockiego o istocie człowieczeństwa. Przyjmując perspektywę mędrca, który w spojrzeniu na ludzkie życie uwzględnił zarówno przesłanie biblijne (odwołując się do idei vanitas), jak i uzgodnioną z wiarą chrześcijańską filozofię stoicką, modelowej egzystencji upatrywał w warunkach dalekich od bitewnego zgiełku. Jest to - mówiąc w uproszczeniu - życie szlacheckiego myśliciela, świadomego potrzeby zgłębienia swojej kondycji oraz pośmiertnych konsekwencji ziemskiej wędrówki. Niemniej nie biblioteka i nie klasztor są najwłaściwszym miejscem osiągania tych celów, lecz właśnie ziemiański folwark. Harmonizując ten model egzystencji z powinnościami rycerskimi, nie miał Potocki wątpliwości, który jest nadrzędny ${ }^{57}$.

Oba wzorce egzystencjalne uzgadniał również Wespazjan Kochowski w opublikowanym w roku 1674 zbiorze Niepróżnujące próżnowanie, co zostało zaznaczone już na frontyspisie książki. Na pierwszym planie u stóp grającego na lutni poety umieszczono elementy uzbrojenia: ozdobiony krzyżem pancerz (sugeruje to obowiązek obrony chrześcijaństwa przed poganami), miecz, tarczę, kopię, sajdak z łukiem i strzałami (na sajdaku widnieje herb „Nieczuja”, co wskazuje, że alegoryczne

56 Nie sposób zgodzić się z twierdzeniami J. Winiarskiego (idem, Jesień Sarmatów w epice Wactawa Potockiego. Nowe tezy, w: Lektury Wactawa Potockiego, red. B. Puchalska-Dąbrowska, Białystok 2014, s. 147-171), który uważa, że wprowadzenie do eposu opisu rzezi mołdawskich cywilów dokonanej przez ciurów obozowych z armii Chodkiewicza, „rozsadza spójność formalną i patriotyczną poematu heroicznego o czynach "rycerzy chrześcijańskich«, rodzi konflikt etyczny”, ibidem, s. 156. Nie sądzę, by Potockiemu przeszło w ogóle przez myśl, by haniebny czyn czeladzi żołnierskiej zaliczyć do porządku heroicznego, a ją samą do rycerzy.

57 Podobne spostrzeżenia miała E. Jażdżewska-Goldsteinowa, Dwie prawdy w „Wojnie chocimskiej” Wactawa Potockiego, „Poezja”, 12, 1977, 5/6, s. 193. Nadmienić jednak należy, że w twórczości Potockiego o wydźwięku satyryczno-publicystycznym, choćby w utworach Ogród czy Moralia, życie ziemiańskie bywa traktowane jako odciągające ziemian od obowiązków obywatelskich; zob. M. Eustachiewicz, Liryka Wespazjana Kochowskiego, w: M. Eustachiewicz, W. Majewski, Nad lirykami Wespazjana Kochowskiego, Wrocław 1986, s. 167-168. Z kolei w pieśni refleksyjnej Żywot ziemiański spokojny i szczęśliwy (z cyklu Pieśni nabożne) substytutem udziału w wojnie stało się dla ziemianina jedynie polowanie, co każe przyjąć, że wypowiadane poglądy zależały od charakteru utworu. W Transakcyi wojny chocimskiej jako eposie - więc gatunku z zasady dążącym do ogarnięcia wycinka uniwersum - owe tendencje wyraźnie się zbiegają. 


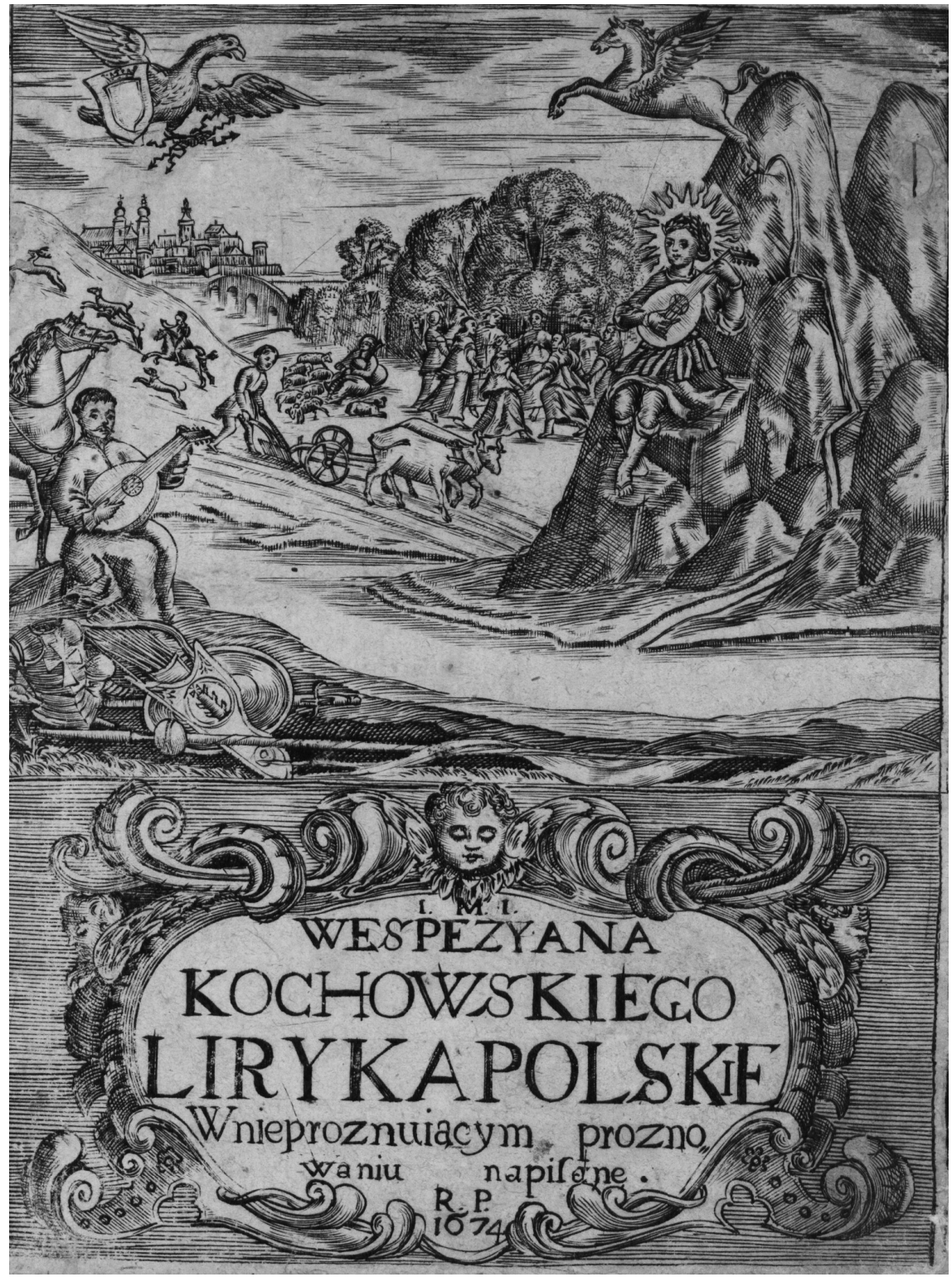

Il. 1. W. Kochowski, Niepróżnujące próżnowanie ojczystym rymem na liryka i epigramata polskie rozdzielone, Kraków 1674, rycina z frontyspisu; reprodukcja z: egz. BN, sygn. XVII 3.2122 
przedstawienie odnosi się do autora tomu), za nim ukazano wierzchowca, a w planie dalszym czytelnik widzi ziemianina, którego przedstawiono za pomocą umownych figur (oracza, pasterza, myśliwego), obok tańczących - najprawdopodobniej podczas święta sobótkowego panien (zob. il. 1). Utwory pieśniowe zawarte w tomie poruszają zarazem tematykę ziemiańską i militarną, tworząc - w nawiązaniu do tradycji horacjańskiej oraz czarnoleskiej - złożoną wypowiedź aksjologiczną. Odwołując się zarówno do literackich szablonów pochwały wsi, jak i własnych doświadczeń, kreował poeta wizję arkadii ziemiańskiej jako sankcjonowanego przez Stwórcę dziedzictwa przodków, pozwalającego żyć skromnie, lecz cnotliwie i w szczęściu. Wojna z jednej strony niweczy ten Boży ład, napawa trwoga, prowadzi do czynów niegodnych, z drugiej - rycerska odwaga i ofiarność zapewnia nieśmiertelną sławę oraz zbawienie. Uznając, jak niektórzy jego poprzednicy, pierwszy model za najlepszy, dawał jasno do zrozumienia, że służba żołnierska jest szlacheckim obowiązkiem. Zaliczył ją do powinności stanowych, warto nadmienić, nie jako teoretyk, lecz doświadczony żołnierz z czasów panowania Jana Kazimierza. Dawał temu wyraz przede wszystkim w pochwałach zmarłych na polu bitwy. Pocieszając Ostafieja Dunina Rzuchowskiego po stracie syna Andrzeja (najprawdopodobniej zginął pod Beresteczkiem), stwierdzał w nawiązaniu do starego etosu:

Przyznam i ja, którym stojąc wedle,

Widział odwagę jako we zwierciedle

Sarmackiej cnoty, gdy żywym impetem

Wpadał na hufce odwrócone grzbietem.

Tam, pokazawszy dzielność swą wspaniałą,

Legł uderzony w serce kulą śmiałą,

Wesoły jednak z tej podjętej rany,

Gdy widział klęską zrażone pogany.

Zaczem ten statut, ojcze, łzy ociera:

Kto się urodził, trzeba, że umiera.

To mężnym jednak pociechą jedyną,

Kiedy nie w łóżku, ale w polu giną ${ }^{58}$. (w. 21-32)

58 W. Kochowski, Utwory poetyckie, oprac. M. Eustachiewicz, Wroctaw 1991, s. 36: Niepróżnujace próżnowanie: Lyrica I 14; zob. M. Eustachiewicz, op. cit., s. 152-196; A. Nowicka-Jeżowa, Barok polski między Europa i Sarmacja, cz. 1: Profile i zarysy catości, Warszawa 2009-2011, s. 262-273; G. Trościński, Arkadyjskie miejsca szczęśliwe w liryce Wespazjana Kochowskiego, w: Staropolskie Arkadie, s. 273-282. 
W krótkim cytacie dostrzec można zamiar uwznioślenia indywidualnego męstwa oraz śmierci poniesionej za ojczyznę, które stanowią odwzorowanie „sarmackiej cnoty”, zatem cnoty będącej legatem przekazanym współczesnej szlachcie przez antenatów.

W literaturze przedmiotu dotyczącej omawianego nurtu zwraca się uwagę na kolizję ideałów rycerskich i ziemiańskich mającą skutkować zdecydowaną postawą antymilitarystyczną ${ }^{59}$. Rzeczywiście zalecenia sielskiego bytowania, bogactwo argumentów za nim przemawiających i opisów przyjemności mu towarzyszących przytłaczają myśli o zobowiązaniach militarnych szlachty, ale ich przecież całkowicie nie unieważniają. Jakkolwiek w poezji ziemiańskiej nie występuje postać Cyncynata, uznawanego czasem za figurę najlepiej ucieleśniającą autostereotyp polskiego szlachcica ${ }^{60}$, to jednak pamięć o powinnościach rycerskich stanu - co nie zostało dotąd zauważone przez badaczy ujawnia się w niej na wiele sposobów, w różnym natężeniu i z rozmaitych pobudek, zwłaszcza u piewców sielskiego bytowania tworzących w pierwszych dekadach drugiej połowy XVII stulecia (Borzymowski, Potocki, Kochowski, nieco wcześniej Jeżowski), gdy potencjał militarny Rzeczypospolitej okazał się iluzoryczny.

Właściwie tylko Domaniewski zanegował in extenso wojnę z religijno-etycznego punktu widzenia, dyskredytując jednocześnie kult

59 Zob. A. Karpiński, op. cit., s. 8-9, 53-57, 180; J. S. Gruchała, S. Grzeszczuk, op. cit., s. 24-25, 45, 61-62. Za nieporozumienie uznać należy stanowisko dwóch ostatnich badaczy (ibidem, s. 8), utrzymujących, że dokonana m.in. przez Kochanowskiego w pieśni Panny XII nobilitacja wieśniaka, ziemianina, „oracza”, który „wszedł do grona bohaterów literackich epoki, eliminując w tej funkcji, a w każdym razie na jedno przynajmniej stulecie usuwając w cień rycerza i świętego".

60 Por.: „Losy Cyncynata stały się idealną prefiguracją żywota szlachcica polskiego nowego Rzymianina: retora wsławionego męstwem i umiłowaniem pokoju, który przyjmuje osobistą odpowiedzialność za losy ojczyzny (stąd liberum veto) i działa realistycznie, konstruktywnie i owocnie, zasługując na immortalitas in memoria et litteris. Postać rzymskiego bohatera miała (w intencji ideologów) scalać wzorzec osobowy obywatela: mówcy, żołnierza i oracza”, A. Nowicka-Jeżowa, op. cit., s. 237. Autorka tych słów nie wskazała jednak żadnej wypowiedzi z epoki, w której tego rodzaju poglądy były sformułowane. Zob. też J. S. Gruchała, S. Grzeszczuk, op. cit., s. 29-30; R. Krzywy, Ideologia sarmacka wobec tradycji antycznej i renesansowego humanizmu (wprowadzenie do zagadnienia), w: Humanistyczne modele kultury nowożytnej wobec dziedzictwa starożytnego, red. M. Prejs, Warszawa 2010, s. 212. 
bohaterstwa jako takiego, który jego zdaniem sugeruje, że zwycięstwa są dziełem ludzi, nie Boga. Rewidował moralny wymiar wojaczki także Morsztyn, traktując ją jako zajęcie zarówno odzierające z godności, jak i prowadzące do potępienia, lecz odnosił swe rozważania przede wszystkim do własnej biografii. Prywatne względy kazały w ziemiańskiej arkadii wyciszyć dźwięk trąb wojennych także Zbylitowskiemu i Potockiemu, lecz przecież realistyczne spojrzenie na rzeczywistość nie pozwalało im o nich zapomnieć. O ile Zbylitowski w ogóle nie kłopotał się stanowymi powinnościami, o tyle Potocki wręcz przeciwnie. Odwołując się do topiki heroicznej, propagował zatracony w jego przekonaniu ideał szlachcica-rycerza. Podobnie czynił Kochowski w zbiorze pieśniowym. Obaj twórcy dostrzegali konflikt omawianych etosów, uznawali jednak zobowiązania stanowe za rzecz bezdyskusyjną. By złagodzić antagonizm, przyjęli ujęcie hierarchiczne, które pozwalało żywot spokojny sytuować ponad służbami marsowymi. Zbieżne podejście wyrażała już zresztą poezja czarnoleska. Kochanowski w zawierających starannie przemyślany program aksjologiczny Pieśniach zalecał oba modele jako odpowiednie dla szlachetnie urodzonych, choć większy nacisk kładł na cnoty obywatelskie, w publicystycznym Satyrze zdawał się narzekać na gospodarskie zajęcia szlachty, lecz w utworach komentujących wybory osobiste wyżej stawiał ziemiańską idyllę. Wyraźnie natomiast harmonizował omawiane ideały Borzymowski, nie przesądzając o wyższości żadnego. Utrzymując znaczenie wzorców heroicznych podczas wojny, punktem odniesienia dla szlacheckiego bytowania w czasach pokoju uczynił wyobrażenia o arkadii ziemiańskiej. O obowiązku służby dla ojczyzny przypominał też Jeżowski, szukając jednocześnie powodów odejścia od dawnych wzorów. Za spadek bojowego potencjału stanu obwinił kupców, którzy rzekomo doprowadzili szlachtę do masowego porzucania wsi i przenosin do miasta, co skutkowało jego zdaniem wyludnianiem się województw, a także potrzebą opłacania najemników obcego autoramentu. Inni genezy zaburzenia porządków oraz niedomagania obronności kraju dopatrywali się w zajmowaniu się przez szlachtę handlem (Słupski) oraz w prowadzących do zubożenia i zniewieściałości zbytkach (Słupski, Potocki). Zdarzają się też głosy, które rolę szlachetnie urodzonych ziemian ograniczają do zapewnienia armii aprowizacji (Zbylitowski, Słupski).

Stwierdzić zatem należy, że poszczególni twórcy omawianego nurtu nie wypowiadają się jednym głosem, wyrażając nieraz zgoła odmienne poglądy na temat zadań stanu wobec militarnych potrzeb 
ojczyzny. Na głoszone przekonania wpływ wywierało to, czy utwór przedstawiał prywatne stanowisko, czy też był pisany z zamysłem parenetycznym albo propagandowym, choć oczywiście w obu przypadkach udostępnienie go drukiem stanowiło o udziale w publicznej wymianie poglądów. W pierwszym wypadku jednak upodobanie do spokojnego żywota dawało o sobie znać mocniej kosztem przywiązania stanu do mitów rycerskich. Niektórzy autorzy próbowali też relatywizować szlacheckie zobowiązania militarne, sytuując tradycje ziemiańskie w czasach przodków, a nawet zakotwiczając je w przeszłości biblijnej, inni przywoływali religijny punkt odniesienia, by móc spojrzeć na zalecany bądź negowany model życia z perspektywy spraw ostatecznych.

\section{Bibliografia}

Źródła

Borzymowski M., Morska nawigacyja do Lubeka, oprac. R. Pollak, Gdańsk 1971

Domaniewski J., Byt ziemiański i miejscki, Lubcz 1620

Fredro A. M., Kwestia wojskowa, czyli o prawidtach wojny i pokoju dwie ksieggi, tł. J. Chmielewska, B. Bednarek, wstęp i przyp. M. Tracz-Tryniecki, Warszawa 2015

Kochanowski J., Carmina Latina. Poezja tacińska, t. 3: Komentarz, oprac. Z. Głombiowska, Gdańsk 2013

Kochanowski J., Dzieła polskie, oprac. J. Krzyżanowski, Warszawa 1982

Kochanowski J, Elegiarum libri quattuor, ed. critica commentata a cura di F. Cabras, Firenze 2019

Kochanowski J., Poematy okolicznościowe, oprac. R. Krzywy, Warszawa 2018 Kochanowski J., $Z$ tacińska śpiewa Stowian Muza. Elegie, foricenia, liryki, tł. L. Staff, wstęp Z. Kubiak, Warszawa 1982

Kochowski W., Utwory poetyckie, oprac. M. Eustachiewicz, Wrocław 1991

Morsztyn H., Światowa Rozkosz z ochmistrzem swoim i ze dwunasta swych stużebnych panien, w: idem, Wybór poezji, wstęp i oprac. R. Grześkowiak, Wrocław 2016

Morsztyn Z., Wybór wierszy, oprac. J. Pelc, Wrocław 1975

Potocki W., Wojna chocimska, oprac. A. Brückner, Kraków 1924

Rej M., Żywot cztowieka poczciwego, oprac. J. Krzyżanowski, Wrocław 1965

Słupski S., Zabawy orackie (1618) / Jeżowski W. S., Oekonomia (1638), wyd. J. Rostafiński, Kraków 1891

Zbylitowski A., Wiersze zebrane, oprac. A. Kochan, teksty łac. tł. i oprac. E. Żybert-Pruchnicka, Warszawa 2018 


\section{Opracowania}

Backvis C., Panorama poezji polskiej okresu baroku, t. 1, tt. W. Błońska-Wolfratch, A. i K. Choińscy, G. Majcher, red. nauk. A. Nowicka-Jeżowa, R. Krzywy, Warszawa 2003

Baczewski S., Szlachectwo. Studium z dziejów idei w piśmiennictwie polskim (druga potowa XVI wieku - XVII wiek), Lublin 2009

Bodniak S., Cikowski Stanistaw, PSB, 4, 1938, s. 72-73

Brückner A., Wiersze zbieranej drużyny, „Biblioteka Warszawska”, 1891, 3, s. $409-439$

Budzyński J., Sarmackie echa $w$ literaturze tacińskiej na Ślasku XVI-XVII wieku, w: Sarmackie theatrum, t. 1: Wartości i stowa, red. R. Ocieczek, współudz. B. Mazurkowa, Katowice 2001, s. 22-36

Cetwiński M., Narzędzia gospodarcze w heraldyce jako świadectwo przemian szlacheckiego etosu, „Rocznik Polskiego Towarzystwa Heraldycznego” n.s., 18, 2019, s. $5-11$

Eustachiewicz M., Liryka Wespazjana Kochowskiego, w: M. Eustachiewicz, W. Majewski, Nad lirykami Wespazjana Kochowskiego, Wrocław 1986, s. $7-226$

Gałaj R., Życie codzienne szlachty polskiej w okresie sarmatyzmu, Szczecin 1998

Glomski J., The Role of „imitatio” in Jan Kochanowski's „Elegiae”, „Lyricorum libellus”, and „Pieśni”, „Oxford Slavonic Papers”, 20, 1987, s. 34-59

Gruchała J. S., Grzeszczuk S., Staropolska poezja ziemiańska, w: Staropolska poezja ziemiańska. Antologia, oprac. J. S. Gruchała, S. Grzeszczuk, Warszawa 1988 , s. $5-88$

Huizinga J., Jesień średniowiecza, tł. T. Brzostowski, wstęp H. Barycz, posł. S. Herbst, Warszawa 1992

Graciotti S., Podwójne oblicze baroku, tł. W. Jekiel, „Barok”, 2, 1995, 2, s. $11-20$

Inglot S., Wstęp, w: A. Gostomski, Gospodarstwo, Wrocław 1951, s. III-XXXIX Jażdżewska-Goldsteinowa E., Dwie prawdy w „Wojnie chocimskiej” Wactawa Potockiego, „Poezja”, 12, 1977, 5/6, s. 189-198

Kaczmarek M., Sarmacka perspektywa stawy. Nad „Wojna chocimskq" Wactawa Potockiego, Wrocław 1982

Karpiński A., Staropolska poezja ideatów ziemiańskich. Próba przekroju, Wrocław 1983

Kochan A., Arkadia Andrzeja Zbylitowskiego. Uwagi do „Żywota szlachcica we wsi" i „Wieśniaka”, w: Staropolskie Arkadie, red. J. Dąbkowska-Kujko, J. Krauze-Karpińska, Warszawa 2010 (Studia Staropolskie. Series Nova, t. 29 [85]), s. 236-245

Koehler K., Jakie poglady religijne mógt mieć Jan Kochanowski? Kilka uwag na marginesie lektury „Zgody”, „Satyra” $i$ „Wróżek”, w: idem, Rzeczpospolita, 
obywatelskość, wolność. Szkice o polskim pisarstwie politycznym XVI wieku, Warszawa 2016, s. 141-187

Kolarzowski J. J., Idea praw jednostki w pismach braci polskich. U narodzin nowożytnej koncepcji praw cztowieka, Warszawa 2009

Kot S., Urok wsi i życia ziemiańskiego w poezji staropolskiej, Warszawa 1937

Kotarski E., Sarmaci i morze. Marynistyczne początki w literaturze polskiej XVI-XVII wieku, Warszawa 1995

Krzewińska A., Pieśn ziemiańska, antyturecka i refleksyjna. Studia nad wybranymi gatunkami staropolskiej liryki XVI i XVII wieku, Torun 1968

Krzywy R., Ideologia sarmacka wobec tradycji antycznej i renesansowego humanizmu (wprowadzenie do zagadnienia), w: Humanistyczne modele kultury nowożytnej wobec dziedzictwa starożytnego, red. M. Prejs, Warszawa 2010, s. $177-218$

Krzywy R., Od hodoeporikonu do eposu peregrynackiego. Studium z historii form literackich, Warszawa 2001

Krzywy R., Poezja staropolska wobec genologii retorycznej. Wprowadzenie do problematyki, Warszawa 2014

Kuran M., Obraz rycerstwa-szlachty $w$ literaturze okolicznościowej i parenetycznej poczatku XVII w., „Rocznik Polskiego Towarzystwa Heraldycznego” n.s., 18, 2019, s. 91-122

Leszczyński R., Marcin Borzymowski na Lubelszczyźnie, „Prace Polonistyczne”, 23, 1967 , s. 98-114

Maciszewski J., Szlachta polska i jej państwo, Warszawa 1969

Mańkowski T., Genealogia sarmatyzmu, Warszawa 1946

Nowicka-Jeżowa A., Barok polski między Europa i Sarmacją, cz. 1: Profile $i$ zarysy catości, Warszawa 2009-2011

Pelc J., Rękopiśmienna wersja "Sobótki” Jana Kochanowskiego, w: Miscellanea staropolskie. 3, [red. R. Pollak], Wrocław 1969 (Archiwum Literackie, t. 14), s. 9-53

Pelc J., Wstęp, w: Z. Morsztyn, Wybór wierszy, oprac. J. Pelc, Wrocław 1975, s. III-CII

Pollak R., Wstęp, w: M. Borzymowski, Morska nawigacyja do Lubeka, oprac. R. Pollak, Gdańsk 1971, s. 5-22

Srogosz T., Życie codzienne żotnierzy armii koronnej i litewskiej $w$ XVII wieku, Oświęcim 2018

Stroynowski A., "Śmierć chwalebna” w propagandzie patriotycznej epoki stanistawowskiej, „Kwartalnik Historii Kultury Materialnej”, 64, 2016, 2, s. $239-248$

Szczerbicka-Ślęk L., W kręgu Klio i Kalliope. Staropolska epika historyczna, Wrocław 1973

Świderska-Włodarczyk U., Homo nobilis. Wzorzec szlachcica w Rzeczypospolitej XVI i XVII wieku, Warszawa 2017

Tomasik T., Wojna - meskość - literatura, Słupsk 2013 
Trościński G, Arkadyjskie miejsca szcześliwe w liryce Wespazjana Kochowskiego, w: Staropolskie Arkadie, red. J. Dąbkowska-Kujko, J. Krauze-Karpińska, Warszawa 2010 (Studia Staropolskie. Series Nova, t. 29 [85]), s. 267-283 Trościński G., Treści przypisywane pojęciu Boga w staropolskiej poezji ziemiańskiej, w: Bóg w jezykach, tekstach artystycznych i narracjach, red. A. Różyło, Sandomierz 2006, s. 59-76

Winiarski J., Jesień Sarmatów w epice Wactawa Potockiego. Nowe tezy, w: Lektury Wactawa Potockiego, red. B. Puchalska-Dąbrowska, Białystok 2014, s. $147-171$

Witkowska A., Stawianie, my lubim sielanki..., Warszawa 1972

Wyczański A., Polska - rzecza pospolita szlachecka 1454-1764, Warszawa 1965

\section{The Idyllic Existence of the Nobility and the Estate Duties of Knights in the Light of Old Polish Landowning Poetry}

The study analyses the most important statements made by the authors of the so-called old Polish landowning poetry, which - creating a distinct current - from the mid-sixteenth century on considered the rural existence of the nobility to be the optimal existential model, ensuring their prosperity, security, independence, family happiness, and many other pleasures resulting from communing with nature or neighbourly contacts. Obviously, this model came into conflict with traditional chivalric models. Contrary to the popular opinions, which exclude military issues from the field of vision of the eulogists of the countryside arcadia, the author of the study proves that the negation of the chivalric ethos was not a rule; the writers tried in various ways to reconcile the ideals of the landed gentry and knights. This sometimes depended on the nature of the statement. In autobiographical works, rural life was usually considered the best, while in paraenetic or journalistic pieces, both models were reconciled differently.

Roman Krzywy - profesor w Instytucie Literatury Polskiej Uniwersytetu Warszawskiego, kierownik Zakładu Literatury i Kultury Epok Dawnych. Zajmuje się twórczością pisarzy polskich XVI-XVIII w.

Roman Krzywy - professor at the Institute of Polish Literature at the University of Warsaw, head of the Department of Ancient Literature and Culture. Deals with the works of Polish writers of the sixteenth-eighteenth centuries.

E-mail: r.krzywy@uw.edu.pl 